\title{
Growth rates of the bivalve Macoma balthica in the Wadden Sea during a period of eutrophication: relationships with concentrations of pelagic diatoms and flagellates
}

\author{
J. J. Beukema, G. C. Cadée \\ Netherlands Institute for Sea Research (NIOZ), PO Box 59, Texel, 1790 AB Den Burg, The Netherlands
}

\begin{abstract}
Probably as a consequence of eutrophication, both the length of the annual phytoplankton blooms and the mean concentrations of flagellates (dominated by Phaeocystis pouchetii) have increased in the western part of the Wadden Sea during the last decades. Planktonic diatoms, on the other hand, have hardly increased, but fluctuate heavily from year to year. Among the benthic tidal-flat fauna, which has increased in total numbers and biomass during the last decades, the bivalve Macoma balthica was studied in detail. The $15 \mathrm{yr}$ (1974 to 1989) patterns of its annual growth and condition were compared with abundance patterns in phytoplankton components (during the growing seasons of $M$. balthica). Fluctuations in $M$. balthica were found to parallel fluctuations of planktonic diatoms but not those of $P$. pouchetii. It is concluded that $M$. balthica responded by faster growth and higher condition to better feeding conditions in years of high diatom abundance. Diatoms rather than $P$. pouchetii or other flagellates will be the most important food source for $M$. balthica.
\end{abstract}

\section{INTRODUCTION}

During the last decades, concentrations of both nutrients and phytoplankton have increased in the western part of the Wadden Sea. Increases in nutrient concentrations were particularly strong during the 1970 's, with, in the westernmost tidal inlet, concentrations of total $\mathrm{P}$ roughly tripling and total $\mathrm{N}$ roughly doubling, and remaining at an elevated level during the 1980's (van der Veer et al. 1989).

Increases in phytoplankton abundance were particularly strong in the haptophyte flagellate Phaeocystis pouchetii: the annual period with $>1000$ cells $\mathrm{cm}^{-3}$ of this species increased from ca $20 \mathrm{~d}$ in the early 1970 's to ca $100 \mathrm{~d}$ in the mid-1980's (Cadée \& Hegeman 1986), reaching as much as 5 and 4 mo in 1988 and 1989, respectively (Cadée 1990). Diatoms showed a less consistent change during the same period: although the number of days with $>1000$ cells $\mathrm{cm}^{-3}$ increased from ca 20 in some years in the early 1970 's to $>100$ in some years in the early 1980's (Cadée 1986b), high numbers (ca 100) of such days were also observed in 1969 and 1970 (Cadée 1986b), whereas only 48 such days were counted in 1988 .

Total annual phytoplankton production in the westernmost inlet of the Wadden Sea roughly doubled from ca $150 \mathrm{gC} \mathrm{m}^{-2}$ around 1970 to ca $300 \mathrm{gC} \mathrm{m}^{-2}$ in the early 1980's (Cadée 1986a). A doubling of primary production during this period was also observed in the microphytobenthos on a tidal flat in the western Wadden Sea (Cadée 1984).

Responses of animals to this increased food supply were in the expected direction: both biomass and productivity of the zoobenthos living on the tidal flats in the western part of the Wadden Sea roughly doubled during the 1970 to 1984 period (Beukema \& Cadée 1986). These increases were caused mainly by significantly enhanced numerical densities in almost half of the macrozoobenthic species during the last $20 \mathrm{yr}$ (Beukema 1989), whereas significant decreases did not occur in any macrozoobenthic species. Growth rates, which could be assessed with sufficient precision in a 
few bivalve species only, showed a less clear response, though an increasing trend was suggested in Macoma balthica (Beukema \& Cadée 1986).

In this paper, detailed data will be examined on annual growth rates (both in length and weight) and condition factor in the tellinid bivalve Macoma balthica (L.). These data were obtained by monitoring 15 tidalflat populations during a $20 \mathrm{yr}$ period. During 15 of these years, phytoplankton was monitored at a nearby station in the tidal inlet. Relationships between these 2 long-term data sets will be used to study the responses of the herbivore $M$. balthica to differential changes in the abundance of diatoms, Phaeocystis pouchetii and other flagellates. Did M. balthica respond primarily to the enhanced total food supply or to specific components only?

\section{METHODS AND MATERIAL}

Phytoplankton samples were collected at a frequency of at least once or twice per month at high water at a site in the Marsdiep, the main tidal inlet of the westernmost part of the Wadden Sea (Fig. 1). The site has been sampled regularly year-round since early 1974, though with an interruption from autumn 1976 to

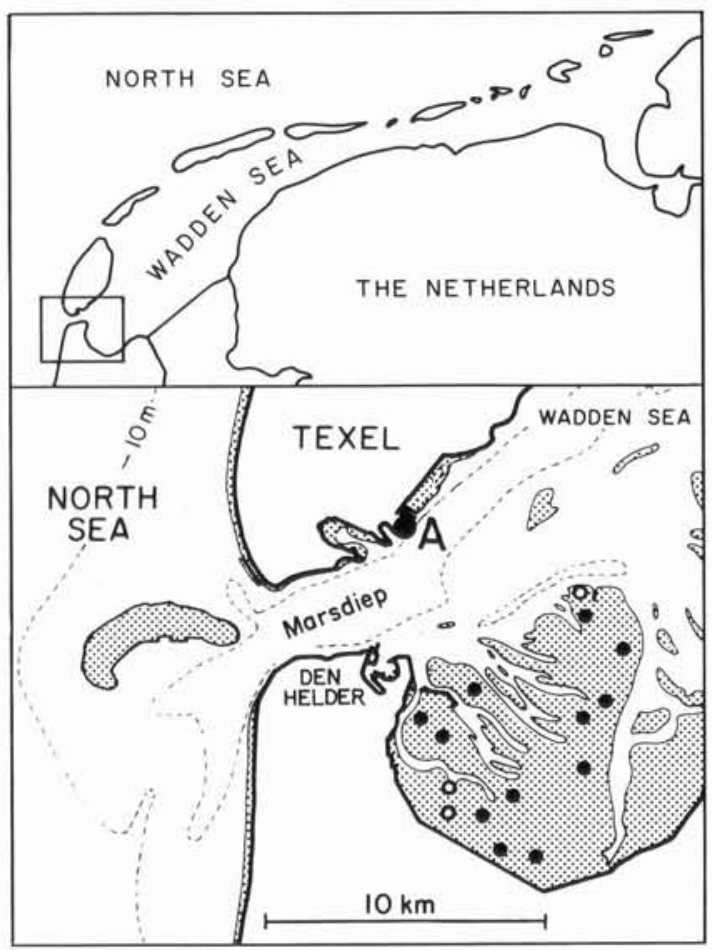

Fig. 1. Location of the one sampling station for phytoplankton in the Marsdiep tidal inlet (denoted by A) and the 15 stations for zoobenthos on Balgzand: $(\bullet)$ the 12 transects sampled twice annually; (o) the 3 more frequently sampled squares. Tidal flats indicated by shading late 1977. Samples were preserved in Lugol and counted with an inverted microscope (usually within $1 \mathrm{mo}$ ). Further details can be found in Cadée (1986b). The numbers used (mean numbers of cells per $\mathrm{cm}^{3}$ of all diatoms together and separately for Phaeocystis pouchetii and for all other flagellates together) are averages of all samples taken during the main growing season of Macoma balthica: March to June, inclusive (Beukema \& de Bruin 1977, Beukema et al. 1985). P. pouchetii was present both as single cells and as colonies. The latter were fragmented during preservation; sometimes vigorous shaking was applied to aid fragmentation in order to be able to count the totals of individual cells.

Chlorophyll a was measured following Lorenzen (1967).

Macoma balthica populations have been sampled at least twice annually (in late winter and late summer) since 1969 at 15 fixed stations scattered on Balgzand, a $50 \mathrm{~km}^{2}$ tidal-flat area in the westernmost part of the Wadden Sea (Fig. 1). To follow changes in more detail, 3 of these stations were sampled more frequently. Specimens were divided into age groups by counting year marks (the method described by Lammens (1967) proved to be reliable: strong year classes could be followed easily throughout several years). Subsequently the soft parts were weighed per $\mathrm{mm}$ group (shell length, L) after drying and again after ashing to obtain a value for ash-free dry weight (AFDW). The nearly-2-yr-old individuals of the late-winter samples were used to estimate the mean length increment (LIN) of the shells during the foregoing year (their second growing season). A correction was used to achieve a standardized estimate (LINc) applying to a specimen with a length of exactly $6 \mathrm{~mm}$ at the start of the growing year (see Beukema et al. 1977).

Values for condition factor $\left(\mathrm{CF}=\mathrm{AFDW} \mathrm{L} \mathrm{L}^{-3}\right.$ ) of the soft parts were obtained from summer samples. Because CF values steadily decrease during summer and autumn (Beukema \& De Bruin 1977), all figures were corrected to a fixed date, viz. 1 July (i.e. near the end of the annual growing season). The rate of the summer decline of CF was estimated each year at the 3 frequently sampled stations and amounted to ca 0.04 units $\mathrm{d}^{-1}$. Two data sets on summer CF were used: (1) mean values $(\mathrm{n}=12)$ for 4 year classes (settled 2, 3, 4 and $>5 \mathrm{yr}$ before) of individuals living at the 3 frequently sampled stations, and (2) mean values $(n=15$ : all stations) for individuals at the end of their second growing season (settled slightly more than 1 yr before). The virtue of estimate (1) is that it is independent of the growth estimates used, because it refers to different age groups, and that only minor corrections were applied, because at least one of the sampling dates was near 1 July. Estimate (2) was used to calculate a stan- 
dardized value for the annual mean weight increment (WINc), i.e. the weight increment during the second growing season of an individual of a standard length of $6 \mathrm{~mm}$ and a CF of $7 \mathrm{mg} \mathrm{cm}^{-3}$ at the start of the season (weighing $1.5 \mathrm{mg}$ AFDW) and a length increase of LINc, according to:

$$
\text { WINc }=\text { CF }(6+\text { LINC })^{3}-1.5 .
$$

These standardized estimates of weight growth can be compared with the observed differences in 1-yr-old individuals between the mean weights at the summer and foregoing winter samplings. These plain estimates suffer from such inconsistencies as interannual differences in sampling dates, length distributions (between years at the start of the season and within years between start and end of the season) and CF at the start of the growing season.

The mean values shown are invariably unweighted means of data from 15 stations (in a few cases from a slightly lower number, viz. when individuals of the proper age were lacking), unless specified otherwise. Pearson correlations were calculated for data pairs of 15 years $(1974,1975,1976$ and 1978 to 1989, incl.). For long-term trends (correlations with year number) Spearman rank correlations were used. For an analysis of the year-to-year variation in linear growth rates (LINc) a 2-way analysis of variance was applied.

A correlation or difference is regarded as non-significant if $p>0.05$; for significant correlations the level of significance is indicated (1-tailed tests).

\section{RESULTS}

\section{Year-to-year variability in phytoplankton}

During the spring months (March to June, incl.) of the 1974 to 1989 period, the number of days Phaeocystis pouchetii bloomed $\left(>1000\right.$ cells $\left.\mathrm{cm}^{-3}\right)$ increased significantly (broken lines in Fig. $2 \mathrm{a} ; \mathrm{r}=+0.77, \mathrm{n}=15$, $\mathrm{p}<0.01$ ). Mean cell numbers also showed an increasing trend (continuous lines in Fig. 2a), but this trend was not significant $(\mathrm{r}=+0.36)$.

As a consequence of the often high concentrations of Phaeocystis pouchetii cells, the cell numbers of the other flagellates were only a minor proportion of all flagellate cells - always less than $30 \%$ and in most years even less than $10 \%$. This group of 'other flagellates' showed an increasing trend during the period of observation (Fig. 2c): both mean numbers of cells per $\mathrm{mm}^{3}$ and numbers of days with $>1000$ cells $\mathrm{cm}^{-3}$ increased significantly $(\mathrm{r}=+0.58$ and +0.50 , both $\mathrm{p}<0.05$ ).

Increases were less clear and non-significant in diatoms, as shown by both numbers of blooming days and cell concentrations (Fig. $2 \mathrm{~b} ; \mathrm{r}=+0.40$ and +0.42 , respectively). Note the relatively low numbers observed in the last 2 years (1988 and 1989).

Chlorophyll concentrations also showed an increasing trend (Fig. 2d), but again it was non-significant ( $\mathrm{r}=$ +0.41 ). Years with spring periods characterized by high chlorophyll concentrations tended to be those with high cell numbers of diatoms $(\mathrm{r}=+0.68, \mathrm{p}<0.01)$ and 'other flagellates' $(r=+0.46)$, but not those with high numbers of Phaeocystis pouchetii cells ( $\mathrm{r}=$ -0.06 ). Years of high diatom densities in spring frequently coincided with springs of high numbers of 'other flagellates' $(\mathrm{r}=+0.45)$, but not with those with high numbers of $P$. pouchetii $(\mathrm{r}=-0.17)$. There was no correlation between years with high numbers of $P$. pouchetii and other flagellates $(\mathrm{r}=+0.02)$.

\section{Year-to-year variability in Macoma balthica}

Data series on length growth of shells are available for 15 stations and 22 years (1968 to 1989). The mean annual length increase of a standard-sized individual (LINc) fluctuated at all stations, though at different levels: growth was invariably slowest at stations above MTL (<50\% immersion) and was maximal at ca $75 \%$ immersion (Beukema et al. 1977). As a consequence of these significant place-to-place differences, the confidence limits around the annual 15-station mean are relatively wide. For a proper evaluation of the year-toyear differences in growth rate, a 2-way analysis of variance was applied to the $15 \times 22 \ln$-transformed individual data, according to the model $\ln (\mathrm{y})=$ constant $+\operatorname{area}_{i}+$ year $_{i}$. Table 1 shows that both the effect of area and year of observation were highly significant. The averages of the relative growth rates showed relatively small standard errors after removal of the area effects (Fig. 3). Therefore, most betweenyear differences in mean annual growth rates are statistically highly significant.

Growth rates were relatively low around 1970, increased over the 1974 to 1987 period, and were low again in 1988 and 1989 (Fig. 3). The increasing trend for the entire $22 \mathrm{yr}$ period was hardly significant $(\mathrm{r}=$ $+0.38, p=$ ca 0.05 ; data from Fig. 3 ) and non-significant for the $15 \mathrm{yr}$ period of phytoplankton observations $(\mathrm{r}=+0.27$; data from Fig. 4a). Only during the 1974 to 1987 period do the data suggest an increasing trend, but the low rates observed in both 1988 and 1989 cause the overall correlations with year number to become non-significant.

Data on condition factor (CF) are available for the 3 frequently sampled plots for the 1968 to 1989 period. Averages (3 stations, 4 age classes, corrected to apply to 1 July) are shown for 1974 to 1989 (Fig. 4b). The 

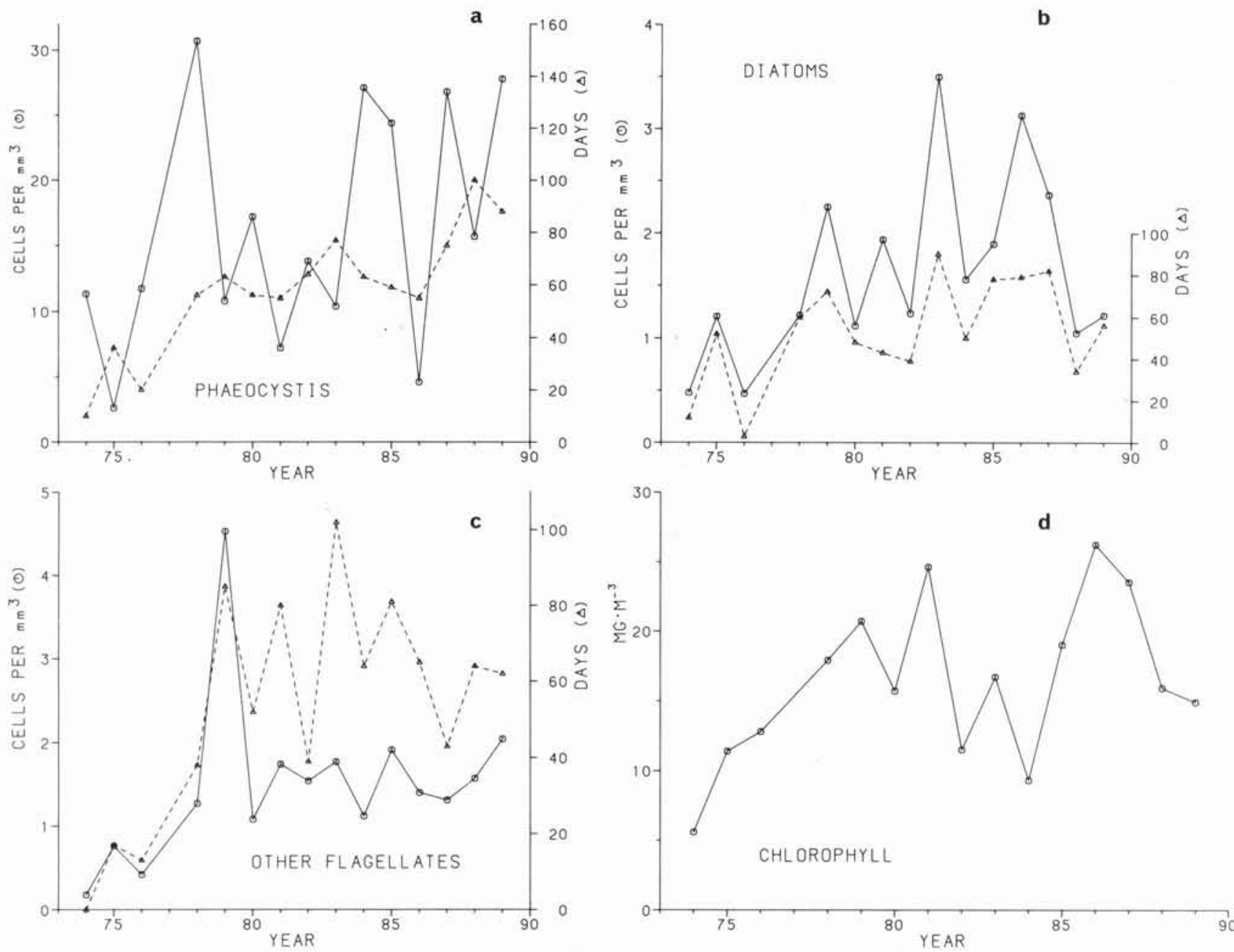

Fig. 2. Plots of 1974 to 1989 data series on phytoplankton, collected during the growing seasons (1 March to 1 July) of Macoma balthica. (a) Phaeocystis pouchetii in mean number of cells $\mathrm{mm}^{-3}$ (continuous lines) and numbers of days with $>1000$ cells $\mathrm{cm}^{-3}$ (broken lines); (b) diatoms in mean number of cells $\mathrm{mm}^{-3}$ (continuous lines) and number of days with $>1000 \mathrm{cells} \mathrm{cm}^{-3}$ (broken lines); (c) other flagellates in mean number of cells $\mathrm{mm}^{-3}$ (continuous lines) and number of days with $>1000 \mathrm{cells}^{-3} \mathrm{~cm}^{-3}$ (broken lines); (d) chlorophyll a concentrations in $\mathrm{mg} \mathrm{m}^{-3}$

year-to-year variation parallelled that of growth rate (compare Fig. 4a): CF values were high in years with rapid growth, i.e. the space within the shells was well filled at the end of a favourable growing season. For the $22 \mathrm{yr}$ set the correlation between annual mean LINc (of 1-yr-old individuals at 15 stations) and annual mean CF (of $2+$-yr-old individuals at 3 stations) was highly significant $(\mathrm{r}=+0.82, \mathrm{p}<0.001)$.

Table 1. Macoma balthica. Results of a 2-way analysis of variance of the 15 (stations) $\times 22$ (years) data for LINc (annual length increment of an individual of standard size)

\begin{tabular}{|lcrrrr|}
\hline Source & $\begin{array}{c}\text { Sum of } \\
\text { squares }\end{array}$ & df & $\begin{array}{c}\text { Mean } \\
\text { square }\end{array}$ & F-ratio & $p$ \\
\hline Area & 6.108 & 14 & 0.436 & 23.845 & $<0.001$ \\
Time & 5.295 & 21 & 0.252 & 13.781 & $<0.001$ \\
Error & 5.379 & 294 & 0.018 & & \\
\hline
\end{tabular}

Annual growth can also be expressed in weight units. As explained in 'Methods and material', 2 estimates of weight (AFDW) gain are available: the uncorrected weight change observed between March and August in ca 1-yr-old individuals $(\Delta \mathrm{g}$; continuous lines in Fig. 4c) and a standardized calculated estimate (WINc; broken lines in Fig. 4c). The latter estimate is bound to be the greater, because it refers to the weight gain up to 1 July, i.e. near the date on which the maximal annual value for AFDW in Macoma balthica is reached (Beukema \& de Bruin 1977). The values for $\Delta g$, on the other hand, apply to a date in August, i.e. after 1 to 2 mo of weight loss. For the rest, the 2 estimates of weight gain were strongly correlated $(\mathrm{r}=+0.94$, $\mathrm{p}$ $<0.001)$.

As expected, annual weight gain was positively correlated with both annual length increase (as LINc was used to calculate WINc, only the correlation with $\Delta \mathrm{g}$ 


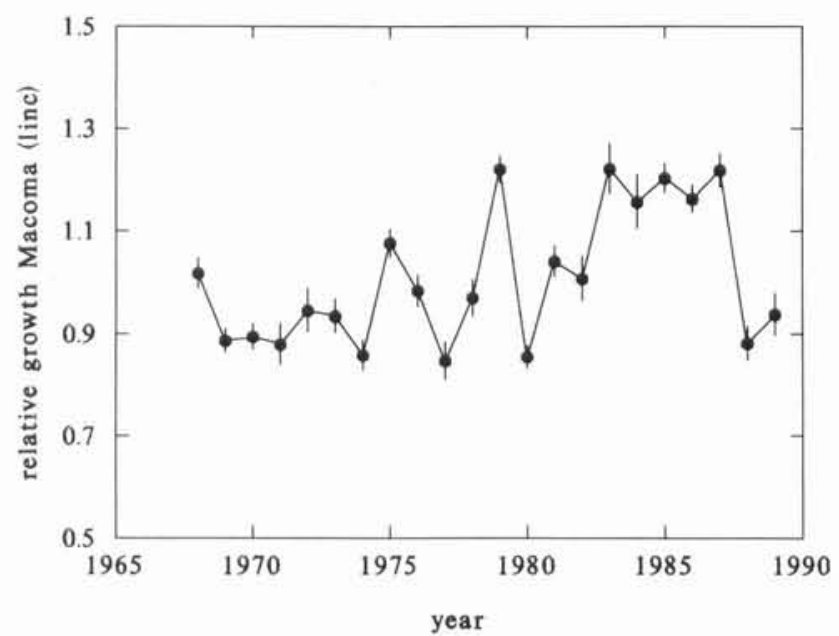

Fig. 3. Macoma balthica. Annual value of mean relative length growth for the 1968 to 1989 period. Means $(n=15)$ with 1 standard error are shown of growth expressed as a proportion of the long-term ( $22 \mathrm{yr}$ ) mean, after removal of the area effect (to reduce the standard errors to apply to year-to-year differences only)

makes sense; it amounted to $+0.91, \mathrm{p}<0.001)$ and summer condition $\mathrm{CF}$ of older individuals $(+0.68$ with $\Delta \mathrm{g}$ and +0.82 with WINc, $\mathrm{p}<0.01$ and $<0.001$, respectively).

Thus, some particular years (e.g. 1979 and 1987) were favourable for growth and condition of Macoma balthica on Balgzand, whereas in other years (e.g. $1974,1977,1980$ and 1988) this species showed low values for these characteristics.

\section{Relations between phytoplankton and Macoma balthica}

Correlation coefficients were calculated for a high number of $15 \mathrm{yr}$ sets of data pairs. All correlations between diatom abundance (mean number of cells $\mathrm{mm}^{-3}$ during the growing season of Macoma balthica) and parameters of $M$. balthica growth were positive and mostly highly $(\mathrm{p}<0.01)$ significant (Table 2 : righthand part of top line and leftmost column). Fig. 5 gives an example: for weight gain WINc $(\mathrm{r}=+0.75, \mathrm{p}<$ 0.01).

On the other hand, the correlations between Macoma balthica parameters and Phaeocystis pouchetii abundance were all non-significant and mostly close to 0 (second line and lower part of second column of Table 2). The correlations between $M$. balthica parameters and abundance of 'other flagellates' were mostly positive, but non-significant (third line of Table 2), whereas the partial correlation coefficients were close to 0 (lower part of third column of Table 2). Correlations with chlorophyll concentrations (fourth line of Table 2) were positive, but hardly significant.
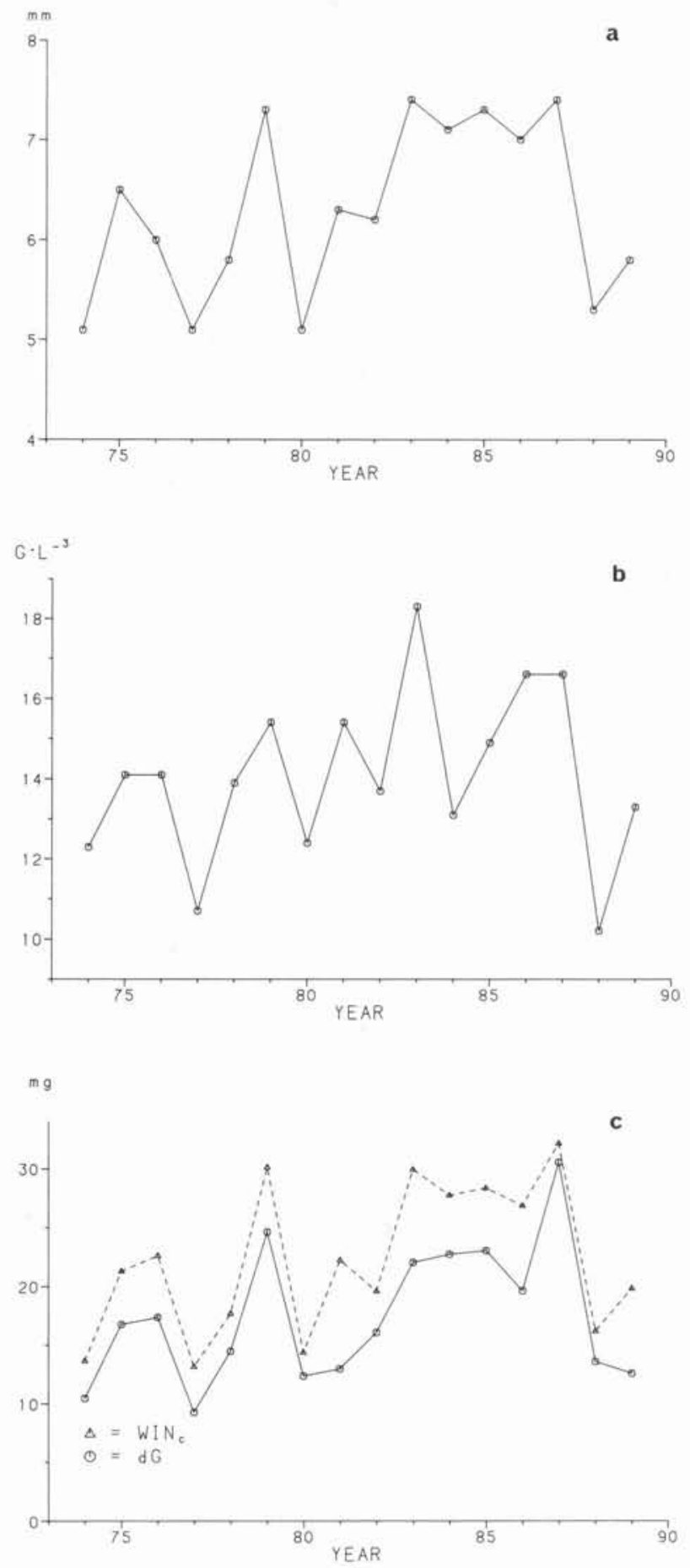

Fig. 4. Macoma balthica. Changes during the 1974 to 1989 period in some parameters of the population on Balgzand. (a) Mean annual length increase (LINc in $\mathrm{mm}$ ) of a standard $6 \mathrm{~mm}$ individual during its second growing season $(\mathrm{n}=15$ : all stations); (b) mean value of condition factor ( $\mathrm{CF}=\mathrm{g} \mathrm{L}^{-3}$ in $\mathrm{mg}$ AFDW $\mathrm{cm}^{-3}$ ) of older $(2+)$ age classes on 1 July $(\mathrm{n}=12$ : 3 stations $\times 4$ age classes); (c) two estimates of annual weight gain (in mg AFDW) during the second growing season: differences between mean weights found in late summer and late winter $(\Delta \mathrm{g}$, continuous lines) and calculated weight increments of a standard individual (WINc, broken lines) 
Table 2. Diagram of Pearson correlation coefficients for pairs of annual mean values of parameters of phytoplankton concentration (during the growing season of Macoma balthica) and of a nearby $M$. balthica population. In addition, the lower left corner shows the partial correlation coefficients (by removal of the influence of the other 2 groups) for each of the 3 groups of algae with the $M$. balthica parameters. Diat.: diatoms; Phaeo.: Phaeocystis pouchetii; Flag.: other flagellates; chlor.: chlorophyll a; see text for definitions of $M$. balthica parameters. Number of pairs $\mathrm{n}=22$ for within- $M$. balthica comparisons and $\mathrm{n}=15$ for withinphytoplankton and between-groups comparisons. Levels of significance (1-tailed): ${ }^{*} \mathrm{p}<0.05, \cdots p<0.01, \cdots p<0.001$

\begin{tabular}{|c|c|c|c|c|c|c|c|c|}
\hline & \multicolumn{4}{|c|}{ Phytoplankton concentrations } & \multicolumn{4}{|c|}{ Parameters of $M$. balthica } \\
\hline & Diat. & Phaeo. & Flag. & Chlor. & LINc & $\mathrm{CF}$ & WINc & $\Delta \mathrm{g}$ \\
\hline Diat. & $x$ & -0.17 & +0.45 & $+0.68^{\cdots}$ & $+0.77 \cdots$ & $+0.84 \cdots$ & $+0.75^{\cdots}$ & $+0.61^{\circ}$ \\
\hline Phaeo. & & $\times$ & +0.02 & -0.06 & 0.00 & -0.20 & +0.05 & +0.19 \\
\hline Flag. & & & $\times$ & +0.46 & +0.44 & +0.28 & +0.46 & +0.37 \\
\hline Chlor. & & & & $\times$ & +0.45 & $+0.58^{\circ}$ & +0.49 & +0.39 \\
\hline LINc & $+0.73 \cdots$ & +0.19 & +0.16 & & $\times$ & $+0.82 \cdots$ & & $+0.91 \cdots$ \\
\hline $\mathrm{CF}$ & $+0.82 \cdots$ & -0.10 & -0.18 & & & $\times$ & $+0.82 \cdots$ & $+0.68 \cdots$ \\
\hline WINc & $+0.71 \cdots$ & +0.25 & +0.18 & & & & $\times$ & $+0.94 \cdots$ \\
\hline$\Delta \mathrm{g}$ & $+0.60^{\circ}$ & +0.36 & +0.11 & & & & & $x$ \\
\hline
\end{tabular}

For all Macoma balthica parameters, the correlations were highest with diatom abundance, followed by those with chlorophyll concentrations. The partial correlation coefficients (lower left part of Table 2) were similar to the plain coefficients in the diatoms, but declined to nearly 0 in the group of 'other flagellates'. In Phaeocystis pouchetii they were somewhat higher, but still near 0 and far from significant. Thus among the 3 algal groups, only diatoms showed a significantly positive relationship with $M$. balthica parameters.

\section{DISCUSSION}

Statistically significant correlations between time series of data indicate probable relationships. These may be direct and causal, but not necessarily so. Caution is warranted in the interpretation of correlations.

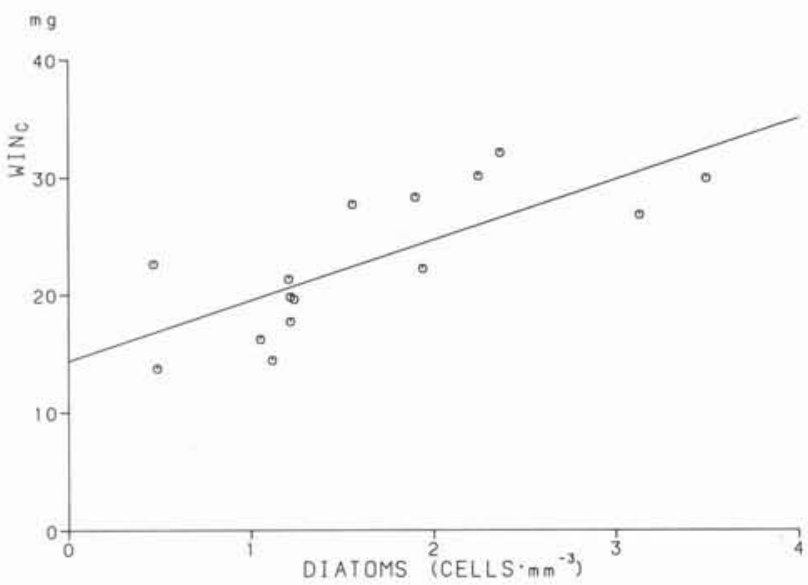

Fig. 5. Macoma balthica. Relationship between mean annual values (for the March to June, inclusive, period) of diatom cell concentrations (DCC, no. $\mathrm{mm}^{-3}$ ) and a standardized estimate of annual weight gain (WINc, in mg AFDW). Best fitting linear regression: WINc $=14.4+5.2 \mathrm{DCC}$
One pitfall of such correlations, the presence of a high degree of autocorrelation, was tested for time lags of 1 to $7 \mathrm{yr}$. This test did not yield any significant correlations.

A causal relationship between food supply and growth rate seems fairly obvious. Nearly all phytoplankton (and microphytobenthos and maybe also bacteria and finely-divided detritus) may contribute to the food of Macoma balthica, because these bivalves are able to ingest food particles of a wide size range: from bacteria of only 1 to $2 \mu \mathrm{m}$ (Harvey \& Luoma 1984) to sand grains of ca $300 \mu \mathrm{m}$ (Gilbert 1977). Though there is a preferred food size of ca $5 \mu \mathrm{m}$, selectivity appears to be weak (Self \& Jumars 1988). Diatoms are an important food item in the stomachs of $M$. balthica living on Balgzand (Kamermans pers. comm.).

Macoma balthica is able to obtain its food by both deposit and filter feeding, but the stomach contents of the Wadden Sea individuals appear to originate for the greater part from the water column (Hummel 1985a, Kamermans, pers. comm.). Among the available food types, detritus and bacteria appear to be of minor importance and chlorophyll concentrations in the water (and not at the sediment surface) appear to be a good overall measure of food supply (Hummel 1985a, b, Thompson \& Nichols 1988). Therefore, the significantly positive correlations observed between (on the one hand) pelagic diatom and chlorophyll concentrations and (on the other hand) the parameters of $M$. balthica growth (LINc, CF, WINc, and $\Delta g_{\text {; }}$ see Table 2) will indeed represent functional relationships between food supply and consumer growth and therefore indicate true causal relationships.

The above-cited studies do not indicate which species groups among the phytoplankton contribute most to the food and growth of Macoma balthica. Because in the present study the correlations with 
diatom abundance were better than those with chlorophyll concentrations (Table 2), the primary factor will have been diatom density during the growing season. Diatoms are indeed the group with the highest correlation with chlorophyll concentrations (Table 2). The group of 'other flagellates' may have contributed, but the low partial correlation coefficients indicate a minor role. This is not surprising, because their cells were generally very small and no more numerous than the much bigger diatoms. Thus, $M$. balthica will have responded by faster growth and higher condition particularly in years with high diatom abundance and the connected $(r=+0.68)$ high chlorophyll concentrations during its growing season.

The role of the often very abundant flagellate Phaeocystis pouchetii needs a different explanation. Though its individual cells are small, they are so abundant during bloom periods that chlorophyll concentrations were high at such times. Apparently, the reason why years of high $P$. pouchetii abundance did not coincide with years of high chlorophyll concentrations $(\mathrm{r}=-0.06)$ is the relatively low abundance of diatoms during the spring periods of such years (compare the slightly negative correlation of $\mathrm{r}=-0.17$ between diatom and $P$. pouchetii abundance, Table 2 ).

The contribution of $P$. pouchetii to the food supply of Macoma balthica appears to be outweighed by that of diatoms. Though $M$. balthica can grow on an exclusive diet of single ( 4 to $8 \mu \mathrm{m}$ diameter) cells of $P$. pouchetii (Kamermans pers. comm.), (partial) correlations between its abundance and parameters of growth of $M$. balthica were invariably low. The average volume of single $P$. pouchetii cells is at least an order of magnitude smaller than that of the 'average' diatom cell in the Wadden Sea area. Because they were on average also an order of magnitude more abundant (compare Figs. $2 \mathrm{a}$ and $\mathrm{b}$ ), their contribution to total phytoplankton biomass will nevertheless have been significant and at times even decisive. High chlorophyll concentrations (comparable to such concentrations at the highest diatom densities) were indeed measured during $P$. pouchetii blooms with few diatom cells. The frequent occurrence of $P$. pouchetii cells in big and mucous colonies may have hampered ingestion by $M$. balthica. These colonies often reach a size of several thousands $\mu \mathrm{m}$ (up to $8 \mathrm{~mm}$ ) and the greater part will therefore be outside the size range of particles that can be ingested by $M$. balthica. In the mussel Mytilus edulis, Pieters et al. (1980) observed poor growth during a part of the growing season with high concentrations of P. pouchetii in the Wadden Sea. They suggest that the mucous colonies prevent food intake in this bivalve. Indeed, Wolters (1989) observed reduced clearance rates and food consumption in $M$. edulis at high $P$. pouchetii concentrations, which could explain low growth rates during periods of blooming $P$. pouchetii.

In any case, the phytoplankton species that responded most clearly to the eutrophication of the Dutch coastal areas and that became the dominating component of the phytoplankton in the western part of the Wadden Sea during the last decade appears to contribute little to the growth of Macoma balthica, being the species in which growth rates have been investigated more thoroughly than in any other herbivore species in this area.

The possible response of Macoma balthica to eutrophication by increasing its annual growth rate is not as simple as we suggested in an earlier paper (Beukema \& Cadée 1986). At that time, we had at our disposal only a data set up to and including 1985, which showed a significantly positive correlation between year number and annual length increase (Fig. 4b of Beukema \& Cadée 1986). Data from 1986 and 1987 corroborated this trend, but during 1988 and $1989 \mathrm{M}$. balthica showed strongly reduced growth rates (Fig. 3). During the growing seasons of the latter 2 years, diatom abundance was also reduced (Fig. 2b), but Phaeocystis pouchetii and other flagellates continued their upward trends (Fig. 2a, c), whereas chlorophyll concentrations remained at a level close to the average of the 1980's (Fig. 2d). Despite a slightly declining trend during the 1980 's, nutrient concentrations are still at a high level and the abundance of $P$. pouchetii and other flagellates indicates a eutrophicated situation during 1988 and 1989. For reasons not fully understood now, diatom abundance was remarkably low in these 2 years and growth rates of $M$. balthica followed diatom concentrations rather than the general eutrophication trend. Thus, for this species more food (in the sense of all phytoplankton together or total chlorophyll) does not simply mean better growing conditions. Such a blackbox approach appears to be too simple. Apparently, only suitable food (and for $M$. balthica this is the diatom part of the total phytoplankton stock) should be taken into account.

\section{LITERATURE CITED}

Beukema, J. J. (1989). Long-term changes in macrozoobenthic abundance on the tidal flats of the western part of the Dutch Wadden Sea. Helgoländer Meeresunters. 43: 405-415

Beukema, J. J., de Bruin, W. (1977). Seasonal changes in dry weight and chemical composition of the soft parts of the tellinid bivalve Macoma balthica in the Dutch Wadden Sea. Neth. J. Sea Res. 11: 42-55

Beukema, J. J., Cadée, G. C. (1986). Zoobenthos responses to eutrophication of the Dutch Wadden Sea. Ophelia 26: $55-64$ 
Beukema, J. J., Cadée, G. C., Jansen, J. J. M. (1977). Variability of growth rate of Macoma balthica (L.) in the Wadden Sea in relation to availability of food. In: Keegan, B. F., Ceidigh, P. O., Boaden, P. J. S. (eds.) Biology of benthic organisms. Pergamon Press, Oxford, p. 69-77

Beukema, J. J., Knol, E., Cadée, G. C. (1985). Effects of temperature on the length of the annual growing season in the tellinid bivalve Macoma balthica (L.) living on tidal flats in the Dutch Wadden Sea. J. exp. mar. Biol. Ecol. 90: $129-144$

Cadée, G. C. (1984). Has input of organic matter into the western part of the Dutch Wadden Sea increased during the last decades? In: Laane, R. W. P. M., Wolff, W. J. (eds.) The role of organic matter in the Wadden Sea. Neth. Inst. Sea Res. Publ. Ser. 10: 71-82

Cadée, G. C. (1986a). Increased phytoplankton primary production in the Marsdiep area (western Dutch Wadden Sea). Neth. J. Sea Res. 20: 285-290

Cadée, G. C. (1986b). Recurrent and changing seasonal patterns in phytoplankton of the westernmost inlet of the Dutch Wadden Sea from 1969 to 1985. Mar. Biol. 93: 281-289

Cadée, G. C. (1990). Eutrophication in Dutch coastal waters. In: Hardwick, D., Heath, T. (eds.) Nutrients in the North Sea. Fertilizer Manufacturers Association, Peterborough, U.K., p. $1-5$

Cadée, G. C., Hegeman, J. (1986). Seasonal and annual variation in Phaeocystis pouchetii (Haptophyceae) in the westernmost inlet of the Wadden Sea during the 1973 to 1985 period. Neth. J. Sea Res. 20: 29-36

Gilbert, M. A. (1977). The behaviour and functional morphology of deposit-feeding in Macoma balthica (Linné, 1758), in New England. J. mollusc. Stud. 43: 18-27

Harvey, R. W., Luoma, S. N. (1984). The role of bacterial exopolymer and suspended bacteria in the nutrition of the

This article was submitted to the editor deposit-feeding clam, Macoma balthica. J. mar. Res. 42: 957-968

Hummel, H. (1985a). Food intake of Macoma balthica (Mollusca) in relation to seasonal changes in its potential food on a tidal flat in the Dutch Wadden Sea. Neth. J. Sea Res. 19: $52-76$

Hummel, H. (1985b). An energy budget for a Macoma balthica (Mollusca) population living on a tidal flat in the Dutch Wadden Sea. Neth. J. Sea Res. 19: 84-92

Lammens, J. J. (1967). Growth and reproduction of a tidal flat population of Macoma balthica (L.). Neth. J. Sea Res. 3: 315-382

Lorenzen, C. J. (1967). Determination of chlorophyll and phaeopigments. Spectrophotometric equations. Limnol. Oceanogr. 12: 343-346

Pieters, H., Kluytmans, J. H., Zandee, D. I., Cadée, G. C. (1980). Tissue composition and reproduction of Mytilus edulis in relation to food availability. Neth. J. Sea Res. 14: 349-361

Self, R. F. L., Jumars, P. A. (1988). Cross-phyletic patterns of particle selection by deposit feeders. J, mar. Res. 46: $119-143$

Thompson, J. K., Nichols, F. H. (1988). Food availability controls seasonal cycle of growth in Macoma balthica (L.) in San Francisco Bay, California. J. exp. mar. Biol. Ecol. 116: $43-61$

Veer, H. W. van der, Raaphorst, W. van, Bergman, M. J. N. (1989). Eutrophication of the Dutch Wadden Sea: external nutrient loadings of the Marsdiep and Vliestroom basin. Helgoländer Meeresunters. 43: 501-515

Wolters, E. (1989). Het effect van de aanwezigheid van Phaeocystis pouchetii in het seston op het energiebudget van de mossel Mytilus edulis. Notitie GWAO-88.1343. Dienst Getijdewateren, Rijkswaterstaat, Middelburg

Manuscript first received: July 3, 1990

Revised version accepted: September 6, 1990 